\title{
Intravenous immunoglobulin treatment in patients with chronic inflammatory demyelinating neuropathy not responsive to other treatments
}

\author{
R Nemni, S Amadio, R Fazio, G Galardi, S Previtali, G Comi
}

\begin{abstract}
Nine patients with chronic inflammatory demyelinating poliradiculoneuropathy (CIDP) were treated with intravenous immunoglobulin. All patients had been previously treated with prednisone and/or plasma exchange without effect. Objective improvement in clinical condition occurred in six patients. One patient became refractory after two treatment courses, two patients had no response. The results indicate that intravenous immunoglobulin has beneficial effects in a high percentage of patients with CIDP who are unresponsive to other treatments.
\end{abstract}

Chronic inflammatory demyelinating polyradiculoneuropathy (CIDP) is a chronic progressive acquired neuropathy thought to be mediated by the immune system. The course of CIDP may be a stepwise or continuous worsening over months or years. Diagnosis is based on clinical symptoms and signs, neurophysiological studies, lumbar puncture, and cerebrospinal fluid examination that fulfil published criteria for CIDP. ${ }^{1}$ Randomised controlled studies have documented that prednisone $^{2}$ and plasma exchange ${ }^{3}$ are both beneficial and these two forms of therapy represent the mainstay of treatment for CIDP. Both treatments, however, have side effects and some patients do not respond to treatment. Approximately $95 \%$ of patients with CIDP initially respond to prednisone, but dose reduction frequently results in a relapse. ${ }^{4}$ Plasma exchange is helpful in patients whose condition is deteriorating rapidly, in nonresponders to prednisone, and in patients who need to avoid prednisone. The beneficial effect of plasma exchange begins to fade 10 to

Table 1 Patient characteristics

\begin{tabular}{lllllll}
\hline Patients & Age/sex & $\begin{array}{l}\text { Disease } \\
\text { duration } \\
\text { (months) }\end{array}$ & $\begin{array}{l}\text { Clinical } \\
\text { form }\end{array}$ & $\begin{array}{l}\text { CSF } \\
\text { protein } \\
(\mathrm{mg} / 100 \mathrm{ml})\end{array}$ & $\begin{array}{l}\text { CSF } \\
\text { cells } \\
\left(\times 10^{\circ} / 1\right)\end{array}$ & $\begin{array}{l}\text { Result } \\
\text { of IVIg }\end{array}$ \\
\hline 1 & 38/F & 14 & $\mathrm{P}$ & 242 & 6 & Unchanged \\
2 & 62/M & 10 & $\mathrm{P}$ & 124 & 2 & Unchanged \\
3 & 63/M & 10 & $\mathrm{P}$ & 89 & 5 & Improved \\
4 & 62/M & 14 & $\mathrm{P}$ & 85 & 0 & Improved \\
5 & 63/M & 18 & $\mathrm{P}$ & 70 & 2 & Improved \\
6 & 52/F & 60 & $\mathrm{P}$ & 375 & 11 & Improved \\
7 & 27/F & 16 & $\mathrm{R}$ & 120 & 1 & Improved \\
8 & $49 / \mathrm{M}$ & 24 & $\mathrm{P}$ & 80 & 2 & Temporarily \\
improved \\
9
\end{tabular}

CSF (upper limit of normal $50 \mathrm{mg} / 100 \mathrm{ml}$ ); $\mathrm{P}=$ progressive; $\mathrm{R}=$ remitting.

Department of of Milan, Scientific Institute S Raffaele, Milan, Italy

R Fazio

G Galardi

G Comi

Correspondence to:

Dr R Nemni, Department of Neurology, IRCCS,

Raffaele, Via Olgettina 60 20132 Milan, Italy.
14 days after treatment has been stopped. ${ }^{3}$ Intravenous immunoglobulin (IVIg) has been reported to have a beneficial effect in patients with $\mathrm{CIDP}^{5-8}$ but the percentage of responsive patients has not been established. Five criteria for the selection of CIDP patients for treatment with IVIg have been suggested by van Doorn et $a^{9}$ : progression of weakness before treatment, no difference in weakness between arms and legs, disease duration less than one year, areflexia of the arms, and motor nerve conduction velocity of the median nerve less than $80 \%$ of the lower limit of normal. However, a recent double-blind placebo controlled study by the same group concluded that better criteria are necessary to select CIDP patients for treatment with IVIg. ${ }^{10}$ In our department prednisone is the first choice treatment for CIDP. Plasma exchange is used less frequently, and only for selected patients. We decided to analyse the usefulness of IVIg for patients in whom either prednisone or plasma exchange or both were not effective.

\section{Patients and methods}

From 1991-93 we treated nine patients fulfilling the diagnostic criteria for CIDP $^{1}$ with IVIg. Six patients had been treated previously with prednisone $(1.5 \mathrm{mg} / \mathrm{kg} / \mathrm{d}$ for two months and then a gradual reduction) which had no effect in four (patients 3, 4, 6, and 7) and produced an unsatisfactory response in two (patients 8 and 9). Two patients had no beneficial effect from either prednisone and plasma exchange (patients 2 and 5) while one (patient 1) experienced a rapid deterioration after plasma exchange. All patients were treated with IVIg (Sandoglobulin, Sandoz, Basel, Switzerland) $0.4 \mathrm{~g} / \mathrm{kg}$, for five consecutive days. The response to therapy was assessed using the modified Rankin scale ${ }^{11}$ at day 20 after the onset of each IVIg course: $0=$ asymptomatic; $1=$ nondisabling symptoms not interfering with lifestyle; $2=$ minor disability symptoms leading to some restriction of lifestyle but not interfering with patients' capacity to look after themselves; $3=$ moderate disability symptoms significantly interfering with lifestyle or preventing totally independent existence; $4=$ moderately severe disability symptoms preventing independent existence, although patients do not need constant attention day and night; $5=$ severely disabled, totally dependent, requiring constant attention day and night. Improvement was defined as at least a one point decrease on the Rankin 
Table 2 Neurophysiological features

\begin{tabular}{|c|c|c|c|c|c|c|c|c|c|}
\hline \multirow[b]{2}{*}{ Patients } & \multicolumn{5}{|c|}{ Electrophysiological findings } & \multicolumn{4}{|c|}{ Electromyographic findings } \\
\hline & $N C V$ & $C B / T D$ & $D M L$ & F-wave & Axonal loss* & Denervation $\dagger$ & MUAPs & changes & Recruitment \\
\hline 1 & Slowed & - & Increased & Absent & 4 & $+\mathrm{L}$ & $\begin{array}{l}\text { prolonged } \\
\text { increased }\end{array}$ & $\begin{array}{l}\text { duration } \\
\text { amplitude }\end{array}$ & + \\
\hline 2 & Slowed & + & Increased & Abnormal & 2 & $++\mathrm{D}$ & $\begin{array}{l}\text { prolonged } \\
\text { increased }\end{array}$ & $\begin{array}{l}\text { duration } \\
\text { amplitude }\end{array}$ & + \\
\hline 3 & Slowed & + & Normal & Abnormal & 4 & $++D$ & $\begin{array}{l}\text { prolonged } \\
\text { polyp }\end{array}$ & $\begin{array}{l}\text { duration } \\
\text { hasic }\end{array}$ & + \\
\hline 4 & Slowed & + & Normal & Absent & 1 & $+++\mathrm{L}$ & $\begin{array}{l}\text { prolonged } \\
\text { increased }\end{array}$ & $\begin{array}{l}\text { duration } \\
\text { amplitude }\end{array}$ & + \\
\hline 5 & Slowed & - & Increased & Absent & 5 & $+++\mathbf{D}$ & $\begin{array}{r}\text { prolonged } \\
\text { polyp }\end{array}$ & $\begin{array}{l}\text { duration } \\
\text { hasic }\end{array}$ & + \\
\hline 6 & Slowed & + & Increased & Abnormal & 3 & $++\mathrm{L}$ & $\begin{array}{l}\text { prolonged } \\
\text { increased }\end{array}$ & $\begin{array}{l}\text { duration } \\
\text { amplitude }\end{array}$ & + \\
\hline 7 & Slowed & + & Increased & Abnormal & 4 & $+\mathrm{F}$ & $\begin{array}{l}\text { prolonged } \\
\text { increased }\end{array}$ & $\begin{array}{l}\text { duration } \\
\text { amplitude }\end{array}$ & + \\
\hline 8 & Slowed & + & Normal & Abnormal & 4 & absent & $\begin{array}{r}\text { prolonged } \\
\text { polyp }\end{array}$ & $\begin{array}{l}\text { duration } \\
\text { hasic }\end{array}$ & ++ \\
\hline 9 & Slowed & + & Increased & Abnormal & 0 & $+F$ & $\begin{array}{r}\text { prolonged } \\
\text { polyp }\end{array}$ & $\begin{array}{l}\text { duration } \\
\text { hasic }\end{array}$ & ++ \\
\hline
\end{tabular}

NCV: Nerve conduction velocity, CB: Conduction block, TD: Temporal dispersion, DML: Distal motor latency, MUAPs: Motor unit action potentials.

«Evaluated as number out of five nerves tested with a decrease of action potential amplitude greater than $50 \%$ of lower limit of normal;

†Fibrillation, positive sharp waves or fasciculations recorded from: $+=$ less than $30 \%$ of explored sites; $++=$ more than $30 \%$ and less than $60 \%$ of explored sites; more than $60 \%$ of the explored sites.

$\ddagger$ Recruitment at maximum voluntary effort: $+=$ poor/single oscillation; $++=$ intermediate pattern; $+++=$ interference pattern.

scale. The same regime was repeated after six to 10 weeks in six of seven responders, selected when at least a one point increase on the Rankin scale had been detected by two investigators. Thereafter, the lowest effective dose which prevented deterioration of the patient was empirically found.

\section{Electrophysiological studies}

Sensory conduction velocities of the median, ulnar, and sural nerves, and motor conduction velocities of ulnar and peroneal nerves were measured before treatment in all patients. The mean amplitude ratio of the ulnar and peroneal nerves was evaluated. This is the ratio of the amplitude of compound motor action potential (cMAP) after proximal (elbow or fibular head) and distal (wrist or ankle) stimulation. Conventional electromyographic evaluation included distal as well as proximal muscles of all four limbs. Five patients $(3,4,5,7,8)$ agreed to a repeat electrophysiolgical examination one month after the second course of treatment to monitor the effects of IVIg. Statistical analysis was performed by student's $t$ test for paired data.

\section{Results}

We treated nine CIDP patients not responsive to prednisone and/or plasma exchange (table 1). There were six men and three women, ranging in age from 29 to 63 years (mean, 53 years) at the onset of CIDP. Disease duration, before IVIg was started, ranged from eight months to five years (mean, 14 months) and the mean follow up was 19 months (range, eight to 35 months). Seven patients had a progressive form, and two had remissions and exacerbations.

Neurophysiological results before IVIg treatment are summarised in table 2 . Seven of nine patients (patients 3-9) improved after treatment with IVIg, one had complete remission after one treatment (patient 9), one became refractory after two courses of treatment (patient 8), and the other five (patients 3-7) needed repeated infusions to maintain the clinical improvement (table 3). The first signs of improvement were seen three to seven days after onset of IVIg treatment. The disability before treatment, 20 days after the onset of the first and second IVIg courses, and after eight months was measured with the Rankin score (table 3). Neurophysiological studies performed after IVIg treatment demonstrated slight changes of mean values of usual conduction tests, not reaching statistical significance (data not shown). Only the mean amplitude ratio of the ulnar nerve showed significant improvement $(p<0.01)$; the mean amplitude ratio of the peroneal nerve was also increased, but the difference was not significant $(p<0 \cdot 18)$.

\section{Discussion}

Our results indicate that IVIg treatment

Table 3 Rankin disability score (0-5)

\begin{tabular}{|c|c|c|c|c|}
\hline Patients & Initial & First IVIg course & Second IVIg course & At 8 months of therapy \\
\hline $\begin{array}{l}1 \\
2 \\
3 \\
4 \\
5 \\
6 \\
7 \\
8 \\
9\end{array}$ & $\begin{array}{l}5 \\
5 \\
5 \\
4 \\
4 \\
3 \\
3 \\
4 \\
3\end{array}$ & $\begin{array}{l}5 \\
5 \\
4 \\
3 \\
2 \\
2 \\
0 \\
2 \\
0\end{array}$ & $\begin{array}{l}5^{\star} \\
5^{\star} \\
3 \\
2 \\
2 \\
2 \\
0 \\
2 \\
\text { ND }\end{array}$ & $\begin{array}{l}- \\
- \\
3 \\
2 \\
2 \\
2 \\
0 \\
4 \\
-\end{array}$ \\
\hline
\end{tabular}


improves neurological function in a high percentage of CIDP patients not responsive to other treatments. The patient who did not show a lasting response to IVIg had some unusual clinical findings including a coarse, irregular tremor, and ataxia. No previous data are available in published reports on the effect of IVIg treatment in CIDP patients with these clinical characteristics.

Among the responders to IVIg, both patients with a relapsing form of CIDP responded very well. It is likely that in this form, in which there is probably an intermittent disruption of the regulatory interactions of the immune system, the immunological balance is more easily restored.

Among our patients only two of six who improved during IVIg treatment, and one of three who did not improve, fulfilled the criteria suggested by van Doorn et $a l^{9}$ predicting a response to therapy.

A clear increase of cMAP amplitude related to functional improvement has been previously demonstrated in individual patients during immunoglobulin or plasma therapy. ${ }^{12}$ However, a more recent study failed to demonstrate any significant improvement of mean cMAP ratio in a group of 15 CIDP patients after IgIV treatment. ${ }^{10}$ In our patients we found a significant increase in mean cMAP amplitude ratio of the ulnar nerve after treatment, whereas the cMAP amplitude ratio of the peroneal nerve did not reach statistical significance. An increase in mean cMAP amplitude ratio represents a decrease in motor conduction block; muscle weakness is either related to axonal loss or conduction block or both. Since the time elapsed between the two neurophysiological examinations was short, it is more likely that in our patients the increase in cMAP amplitude ratio is due to the effects of IVIg on conduction blocks. Consistent with this hypothesis, the time to clinical improvement after IVIg courses of treatment was also short.

Despite the evidence for several pathogenetic humoral immune factors in CIDP it is not clear yet how they influence disease activity. Similarly the biological effects of IVIg have not yet been fully clarified and many mechanisms have been proposed. ${ }^{13}$ Nevertheless, it is well established that IVIg has a role in the treatment of CIDP patients. A large controlled trial comparing IVIg with prednisone is now needed to indicate how IVIg should be used in practice and to address the question of its cost effectiveness.

We are grateful for the financial support of Telethon, Italy for projects 251 and 422 .

1 An Ad Hoc Subcommittee of the American Academy of Neurology AIDS Task Force. Research criteria for diagnosis of chronic inflammatory demyelinating polydiagnosis of chronic inflammatory demyelinating
neuropathy (CIDP). Neurology 1991;41:617-8.

2 Dyck PJ, O'Brien PC, Oviatt K, et al. Prednisone improves chronic inflammatory demyelinating polyradiculoneuropathy more than no treatment. Ann Neurol 1982;11: 136-41.

3 Dyck PJ, Daube J, O'Brien P, Pineda A, Low PA, Windebank AJ, Swanson C. Plasma exchange in chronic inflammatory demyelinating polyradiculoneuropathy. N Engl ₹ Med 1986;314:461-5.

4 Barohn RJ, Kissel JT, Warmolts JR, Mendell JR. Chronic inflammatory demyelinating polyradiculoneuropathy. inflammatory demyelinating

5 Vermeulen M, van der Mechè FGA, Speelman JD, Weber A, Busch HFM. Plasma and gamma-globulin infusion in chronic inflammatory polyneuropathy. $f$ Neurol $\mathrm{Sci}$ 1985;70:317-26.

6 Currò-Dossi B, Tezzon F. High-dose intravenous gammaglobulin for chronic inflammatory demyelinating polyneuropathy. Ital $\mathcal{F}$ Neurol Sci 1987;8:321-6.

7 Faed JM, Day B, Pollock M, Taylor PK, Nukada H, Hammond-Tooke GD. High-dose intravenous human immunoglobulin in chronic inflammatory demyelinating polyneuropathy. Neurology 1989;39:423-5.

8 Van Doorn PA, Brand A, Strengers PFW, Meulstee J, Vermeulen M. High-dose intravenous immunoglobulin treatment in chronic inflammatory demyelinating polyneuropathy: A double-blind, placebo-controlled, crossneuropathy: A double-blind, placebo-con
over study. Neurology 1990;40:209-12.

9 Van Doorn PA, Vermeulen M, Brand A, Mulder PGH, Vasch HFM. Intravenous Immunoglobulin treatment in patients with chronic inflammatory demyelinating polyneuropathy. Clinical and laboratory characteristics associated with improvement. Arch Neurol 1991;48: 217-20.

10 Vermeulen M, van Doorn PA, Brand A, Strengers PFW, Jennekens FGI, Busch HFM. Intravenous immunoglobulin treatment in patients with chronic inflammatory demyelinating polyneuropathy; a double blind, placebo controlled study. I Neurol Neurosurg Psychiatry 1993; 56:36-9.

11 Van Swieten JC, Koudstaal PJ, Visser MC, Schouten HJA, van Gijn J. Interobserver agreement for assessment of van Gijn J. Interobserver agreement for assessme
handicap in stroke patients. Stroke 1988;19:604-7.

12 Van der Meché FGA, Vermeulen M, Busch HFM. Chronic inflammatory demyelinating polyneuropathy. Conduction failure before and during immunoglobulin or plasma therapy. Brain 1989;112:1563-71.

13 Dwyer JM. Manipulating the immune system with immune globulin. N Engl F Med 1992;326:107-16. 